\section{EL SEXO DE LAS METÁFORAS}

\author{
Eulalia Pérez Sedeño \\ Departamento de Ciencia, Tecnología y Sociedad \\ Instituto de Filosofía \\ CSIC
}

\section{THE SEX OF METAPHORS}

\begin{abstract}
The hypothesis that states metaphors are structurally determinant in our social relations, routines, and experience has been accepted broadly in the last decades. Moreover, metaphors are to be found in many different levels of scientific practices, and have a diverse set of functions in science. Therefore, they impregnate all scientific enterprise. In this work we examine selected gender metaphors used in biology. We show metaphors are effective precisely because its effectiveness depends on shared social conventions, kinship relations and, authority that, by convention, is given to those that use them.
\end{abstract}

KEY WORDS: Metaphor; gender and science; contextual values.

\section{Introducción}

Según el Diccionario de la Real Academia de la Lengua Española, la metáfora es un tropo -es decir, un uso de las palabras en sentido diferente al que les corresponde propiamente- que consiste en trasladar el sentido recto de las voces a otro figurado, en virtud de una comparación tácita. Asi pues, lo metafórico se opone a lo literal y se aplica a palabras y oraciones, sus usos y significados. El uso de metáforas en el lenguaje cotidiano es de sobras reconocido, y el estudio de sus aspectos estéticos pertenece a la retórica y la poética; pero su papel en la filosofía y, en concreto, el papel cognitivo de la metáfora, es decir, su función en la adquisición, comunicación e incluso justificación del conocimiento, ha estado sometido a múltiples discusiones, pues plantea cuestiones problemáticas sobre la naturaleza y límites del conocimiento.

Podemos rastrear dos líneas fundamentales de pensamiento sobre la metáfora en occidente. Para la platónica, filosofía y uso metafórico del lenguaje están indisolublemente unidos, mientras que según la aristotélica, aunque en el lenguaje poético el uso de la metáfora puede ser enriquecedor $y$, por consiguiente, permisible, no sucede lo
RESUMEN: La tesis de que las metáforas estructuran gran parte de nuestras relaciones sociales y nuestra experiencia cotidiana ha sido ampliamente aceptada en las últimas décadas. En la ciencia, además, aparecen en muchos niveles y desempeñan diversas funciones, impregnando todo el quehacer científico. En este trabajo se examinan algunas metáforas de género usadas en biología. Se muestra que las metáforas eficaces lo son porque su efectividad depende de las convenciones sociales compartidas, los parecidos de familia ya vigentes y de la autoridad que, por convención, se otorga a quienes las usan.

PALABRAS CLAVE: Metáfora; ciencia y género; valores contextuales.

mismo en el lenguaje científico pues la metáfora produce ambigüedad y equivocidad, en suma, oscuridad, como decía Aristóteles. De la primera se sigue que la metáfora es central al lenguaje y al pensamiento, por lo que la teoría semántica y literaria debe dar cuenta primordialmente de ella; de la segunda, el alejamiento de la metáfora del núcleo del pensamiento y conocimiento, pues es un accidente lingüistico periférico con funciones comunicativas muy específicas.

Dentro del marco de la psicología cognitiva, que supone una reacción contra el positivismo psicológico al subrayar la explicación funcional de los procesos de pensamiento, y dentro de las ciencias cognitivas en general, la metáfora ha tomado gran importancia, pues se ha visto en ella un instrumento psicológico crucial para ampliar y estructurar nuestro conocimiento del mundo. La tesis común de quienes mantienen el contenido cognitivo de las metáforas es que éstas constituyen un componente central en la inferencia y el razonamiento por analogía. La tesis de que las metáforas estructuran una gran parte de nuestras relaciones sociales y de nuestra experiencia cotidiana ha cobrado gran fuerza y ha sido ampliamente aceptada en las últimas décadas². 
También en filosofía de la ciencia, la metáfora ha adquirido gran importancia. Dentro del marco de la denominada "concepción heredada" del positivismo lógico se reconoce que las metáforas desempeñan un importante papel en el desarrollo histórico de la ciencia. Los términos de una teoría, así como las generalizaciones legaliformes pueden usarse o formularse metafóricamente (por ejemplo, en el caso "la naturaleza aborrece el vacío"). Pero, dando por sentada la tesis del doble lenguaje, se considera que en la ciencia hay que aplicar reglas especiales que restrinjan el uso de las metáforas, por lo que, a la larga, se convierten en metáforas muertas, es decir, pasan a tener un significado literal y son sustituidas por neologismos técnicos.

El papel de la metáfora como instrumento heurístico parece estar fuera de discusión. Fue Mary Hesse (1966) una de las pioneras en destacar el papel de los modelos y metáforas no sólo en el contexto de descubrimiento, sino en el de justificación (predicción y contrastación). Sus tesis tuvieron la virtud de poner de manifiesto la función social que tienen la elaboración y comprensión de las metáforas (como veremos más adelante). Podemos encontrar metáforas en todos los niveles: hay metáforas básicas que conceptualizan todo un ámbito de la realidad ("el mundo es una máquina"), o imágenes que se basan en metáforas o modelos mentales; aparecen en la formulación de hipótesis o principios, constituyendo metáforas explícitas ("la lucha por la existencia" en la teoría darwinista) o como modelos matemáticos basados en metáforas, como modelos fuente que permiten generar relaciones causales o funcionales (como en el modelo del átomo como sistema solar) o como analogías que ilustran relaciones específicas. Dado que la metáfora aparece en todos esos niveles, puede desempeñar otras muchas funciones: permite elaborar nuevos modelos, pero también describir y predecir nuevos fenómenos, de modo que impregna todo el quehacer científico, la formulación de hipótesis, recogida de datos, contrastación, evaluación y cambio de teorías.

\section{SeXo, MetÁforas... Y ALGO MÁS}

Una vez se admite que las metáforas desempeñan en la ciencia una función que va mucho más allá de la simple heurística, surgen una serie de cuestiones que convendría responder, como: ¿cuál es el papel que desempeñan en el razonamiento científico? ¿Cuáles, si las hay, son las consecuencias en el desarrollo de la investigación? ¿Cuáles son sus consecuencias normativas, si las hubiere? ¿Cuáles son los procesos por los que cambian? ¿Cómo se relacionan las metáforas en la ciencia con la producción social de la ciencia? ¿Por qué se seleccionan o tienen éxito unas y no otras y por qué la comunidad acepta determinadas metáforas pero no otras? ¿En que medida intervienen en estos aspectos valores contextuales y no estrictamente cognitivos?

Para intentar contestar algunas de ellas, analizaremos un par de ejemplos de las ciencias biológicas. El primer caso elegido es el de la fisiología reproductiva. Como ha señalado Emily Martin (1987, 1991), las metáforas elegidas para describir la ovulación y la espermatogénesis son de tal tipo que, aunque en un principio pudieran concebirse ambos procesos como análogos o semejantes, se presentan como dos procedimientos dicotómicos en los que el primero recibe una valoración negativa frente a la positiva del segundo. Así, en primer lugar, se describe el ciclo menstrual como un fracaso, dado que el objetivo del ciclo es producir óvulos que puedan ser fecundados, a la vez que preparar un lugar adecuado para el desarrollo del embrión. La menstruación, signo evidente de que lo anterior no se ha producido, adquiere un carácter destructivo: la menstruación son los "restos del recubrimiento uterino" que se expulsa dado que no hay embarazo en marcha, es el resultado de la "necrosis o muerte del tejido uterino". En cambio, los textos médicos presentan la creación de millones de espermatozoides, "hasta doscientos millones cada veinticuatro horas"3 (Rayner, 1985, p. 74). Esa producción de esperma es continua, de la pubertad a la vejez. En cambio, la producción de óvulos está determinada al nacer: en el momento de su nacimiento, los ovarios de una niña contienen entre cuarenta mil y trescientos mil óvulos, "de los cuales sólo llegará a evacuar un máximo de quinientos" (ibidem, p. 73). La ovulación se convierte en algo doblemente negativo: los óvulos que no se "evacúan" degeneran, convirtiéndose en un despilfarro; pero, además, "la formación de óvulos es un proceso de maduración más que de elaboración" (ibidem, p. 75), frente a la creación de los espermatozoides. En Mountcastle (1980), la afirmación es semejante: "mientras la mujer se desprende de un solo gameto cada mes, los tubos seminíferos producen millones de espermatozoides cada día". 
En el mismo sentido se pronuncia el texto estándar Biology of the Cell, escrito por Alberts et al., donde se afirma que la ovogénesis es un desperdicio. De 7.000.000 de células germinales ováricas existentes en el embrión femenino, la mayoría degenera en el ovario, de modo que al nacer sólo hay entre 40.000 y 300.000 . Y dice más adelante: "Durante los cuarenta años aproximados de vida reproductiva, sólo se liberan unos 400-500 óvulos... los demás habrán degenerado. Todavía es un misterio por qué se forman tantos óvulos sólo para que perezcan en el ovario". Es decir, no tiene sentido formar algo que no se va a utilizar, se está produciendo un desperdicio de óvulos. Sin embargo, no se hace semejante pregunta, ni valoración, con respecto a los millones de espermatozoides "producidos" diariamente por los varones para que uno sólo pueda unirse al óvulo.

Para que haya desperdicio o despilfarro, tiene que haber exceso. Pero hagamos unos pequeños cálculos. Supongamos que una mujer "libere" 500 óvulos a lo largo de su vida reproductiva y que tenga 2-3 hijos. Eso supondría una inversión de unos 250-170 óvulos por hijo. Ahora bien, supongamos el mismo número de hijos en la vida reproductiva de un varón. Si produce 200.000 .000 de espermatozoides diarios, a lo largo de 40 años (supongamos que está activo hasta los 55 años, aunque sabemos que, aunque la producción de espermatozoides disminuye con la edad), habrá producido 73.000.000.000 de espermatozoides al año, unos 2.920.000.000.000 en toda su vida. Es decir, jhabrá utilizado entre 1.460 .000 .000 .000 y 973.000.000.000 de espermatozoides por hijo!

En la metáfora utilizada en los libros mencionados, se señala de forma significativa que la mujer sólo produce un óvulo, mientras el varón produce millones de espermatozoides; pero podría utilizarse una metáfora alternativa en la que se señalaría la regularidad con que se producen los óvulos y, por tanto, su mayor posibilidad de ser fecundados, mientras se requieren millones de espermatozoides para fecundar un solo óvulo. Así, la metáfora del despilfarro, glorifica la cantidad, aunque se puede oponer la de la eficacia, la fiabilidad o regularidad (Herschberger, 1948; Tomlinson, 1995), invirtiéndose así el significado y considerando que la producción de enormes cantidades de espermatozoides es un gasto, un error. La primera metáfora idealiza los números; la segunda, la eficacia y la regularidad, invirtiendo la imagen del gasto tan usual en las explicaciones de los procesos fisiológicos y socioevolutivos femeninos ${ }^{4}$.

En estos y otros textos, el óvulo se describe como algo grande, aunque pasivo; es liberado (no "sale" por sí mismo del ovario); no se mueve ni viaja, es "transportado por las trompas de Fallopio hasta el útero" (Rayner, p. 75); "La parte terminal de la trompa se coloca en estrecho contacto con el ovario para absorber el óvulo y trasladarlo al interior de la cavidad uterina" (P. Pérez Sanz, p. 42), o "es recogido por succión" (ibidem, p. 45), de modo que "no se pierda por algún lugar del abdomen" (Reyner, p. 75), pues ya se sabe la poca capacidad de orientación que, según dicen algunos psicólogos, poseen las mujeres. Es decir, es arrastrado, se deja llevar, se deja guiar para no perderse, actitudes todas ellas muy femeninas ${ }^{5}$.

Por el contrario, los espermatozoides son pequeños, pero vivaces, activos, "ascienden a través del mucus cervical y del útero", "sólo un espermatozoide consigue penetrar el óvulo" (Pérez Sanz, p. 43); son veloces, nadan contracorriente, poseen una cola potente y hasta cabeza, etc. También aquí se puede invertir el significado metafórico o interpretar de manera diferente la metáfora de la velocidad que se antepone al tamaño y traspone la fragilidad y fuerza de un participante a otro. En resumidas cuentas, las metáforas empleadas subrayan el carácter activo del espermatozoide, su importancia, de una manera que resulta patente también en las imágenes científicas: a pesar de su tamaño las imágenes se presentan de tal manera que parecen enormes [en los seres humanos, el tamaño del óvulo es 250.000 veces el del espematozoide: los espermatozoides (o células espermáticas) consisten en una cabeza de 5-8 $\mu \mathrm{m}$ y una cola de $50 \mu \mathrm{m}$ de longitud].

Por supuesto que éstas no son las únicas metáforas utilizadas. A veces se combinan con otras, como la metáfora de la bella durmiente: "el óvulo es una novia dormida que espera el beso mágico de su pareja que le infundirá el espíritu que le dará la vida" (Schaten \& Schaten, citado en Martin, 1991, p. 51). 0 la metáfora militar: los espermatozoides son aguerridos guerreros que tienen una "misión": "asaltar" el óvulo y "conquistarlo", para lo cual deberán atravesar una serie de peligros (mucus cervical, etc.) en un peligroso viaje a través de la oscuridad de la vagina y el útero al que sólo unos pocos "sobrevivirán" y sólo uno "obtendrá la recompensa". Ese viaje debe hacerse con rapidez, dado que 
"el óvulo morirá en pocas horas a no ser que sea rescatado por el espermatozoide" (Alberts et al., 804). En realidad se sabe que el óvulo puede vivir entre 24-48 horas y que el espermatozoide no es mucho más longevo: sólo aquellos que consiguen atravesar la vagina (en ésta apenas duran una hora) y el cuello del útero pueden vivir unas 72 horas. La metáfora guerrera, pues, se combina con el estereotipo femenino de pasividad y fragilidad ${ }^{6}$.

Además, se dice que los espermatozoides son los que "dan sus genes al óvulo", "activan el programa de desarrollo del óvulo" (ibidem). Es decir, se subraya su agencia activa (¿por qué no al revés, cuando se sabe que participan al 50\%?). No hay que olvidar que la creencia mayoritaria entre los genetistas y entre el público general es que los genes son "los agentes primarios de la vida: las unidades fundamentales del análisis biológico; causan el desarrollo de los rasgos biológicos"7. Esa confianza ciega en el poder activo de los genes ha tenido gran importancia en el desarrollo de la genética desde mediados del siglo XX, no sólo en un sentido interno, sino también externo, pues hace que sea, no sólo socialmente aceptable, sino deseable, financiar la investigación en ese terreno, como se ha visto en la Iniciativa Genoma Humano ${ }^{8}$. Poniendo la agencia y la activación genética en el espermatozoide se subraya, una vez más, su importancia y función preeminentes.

¿Por qué esta oposición negativo/positivo? ¿Por qué no considerar la fisiología reproductiva femenina de una manera positiva? Desde luego, el componente cultural del conocimiento al que contribuyen las metáforas es clave. Obsérvese que las metáforas empleadas corresponden a estereotipos culturales de lo masculino y lo femenino en occidente. Son estereotipos que toman una forma dicotómica y jerárquica, en donde lo femenino se asocia con la pasividad, la fragilidad, la irracionalidad, la subjetividad, etc., y lo masculino con la actividad, la fuerza, la racionalidad, la objetividad'. El óvulo se comporta de una manera "femenina" mientras que el espermatozoide lo hace de una forma "masculina". Se subraya la fragilidad del óvulo a la vez que apasiona la resistencia y la velocidad de los espermatozoides. Los estereotipos nos hacen ver la "bravura" del gameto masculino y la "receptividad" del femenino que implican cuestiones tales como la complejidad, la fuerza, la unicidad, el sacrificio, la capacidad de recursos, el destino, asignando valores positivos a unos y negativos a otros. Estas metáforas "ocultan" hechos bien conocidos como la cantidad de espermatozoides por eyaculación o el tiempo de vida de óvulo y espermatozoide.

Cuando el contenido cultural de una descripción científica no varía, aunque haya nuevos descubrimientos biológicos, la construcción social y cultural de los hechos biológicos se aprecia de mejor manera. Eso se ve de forma especialmente clara gracias al contenido metafórico que subraya las diferencias entre óvulo y esperma y al paralelismo que se establece entre los estereotipos de lo masculino y lo femenino y el espermatozoide y el óvulo. En efecto, lo que sucede es que en las nuevas descripciones y explicaciones, siguen utilizándose las viejas metáforas aunque de manera diferente.

Según las anteriores descripciones, el espermatozoide tenía que atravesar una barrera mecánica para llegar a la parte interna del óvulo, para lo cual se desprendía de su cola. Pero, hace pocos años, una investigación realizada en el Laboratorio de Biofísica de la John Hopkins University, dirigida por Jay M. Baltz, transformó el papel pasivo del óvulo en activo, a la vez que cambiaba la metáfora mecánica. La pregunta que se planteó este grupo de investigadores fue, cuál era la fuerza mecánica que necesitaba la cola del espermatozoide para poder penetrar el óvulo y descubrieron que la fuerza de facto era muy pequeña, lo que contradecía la idea de que el espermatozoide es un poderoso penetrador (curiosamente, este descubrimiento se efectuó con una tecnología muy poco sofisticada disponible desde hace más de 100 años: una pipeta, un microscopio y un manómetro).

Las investigaciones de la John Hopkins concluyeron que la cola del espermatozoide, al igual que la cabeza, se mueve de un lado a otro, llegando incluso a dar la impresión de que intenta escapar y es el óvulo el que lo "atrapa". Todo ello condujo a la observación de diversas enzimas digestivas liberadas por el espermatozoide que disolvían químicamente la zona externa del óvulo, pasándose luego a la observación de moléculas adhesivas, tanto en la superficie del espermatozoide como en la del óvulo, que permiten la unión de ambos. Se pasaba de la metáfora mecánica de la ruptura de la pared, a otra combinada que consideraba que los mecanismos que servían para penetrar el óvulo eran a la vez mecánicos y químicos y ambos se atraían mutuamente. Como ya mostraran los experimentos de biología reproductiva realizados por J. F. Hartman en 
1972, si se mataba un óvulo introduciéndole una aguja, los espermatozoides no podían "penetrar" en él, lo que era un excelente indicio de que espermatozoides y óvulo interactúan entre sí.

Sin embargo, aunque pudiera parecer que estos nuevos descubrimientos finalizaban con la metáfora que conceptualiza los roles de los gametos masculino y femenino según los estereotipos asociados a hombres y mujeres, lo cierto es que no fue así, pues los trabajos escritos seguian hablando del papel activo del espermatozoide frente al pasivo del óvulo... aunque de forma más débil. Por ejemplo, Geral y Helen Schatten afirman que "el óvulo no es sólo una esfera rellena de yema en la que penetra el espermatozoide para crear una nueva vida. Recientes investigaciones sugieren más bien una idea casi herética según la cual espermatozoide y óvulo son compañeros mutuamente activos" (citado en Martin, 1991, p. 52). Aunque esta afirmación parezca debilitar e incluso eliminar la metáfora, lo cierto es que, los mismos autores dicen más adelante que "espermatozoide y óvulo se tocan por primera vez cuando, de la punta de la cabeza triangular del espermatozoide se dispara un fino filamento que arponea el óvulo"10, aunque de hecho, como ellos mismos reconocen, ese arpón no se dispara, sino que se une, molécula a molécula, y a gran velocidad con el óvulo. Ese arpón, se dice más adelante, procede de un almacén de proteínas que se encuentra en el acrosoma ${ }^{11}$ y que puede aumentar de tamaño hasta veinte veces el del espermatozoide hasta alcanzar el óvulo. Si eso es así, la elección de la metáfora del arpón no parece inocente, o mejor dicho, la metáfora del arquetipo es tan fuerte, está cultural y socialmente tan arraigada que se sigue usando. Es decir, se sigue utilizando la metáfora del espermatozoide agresivo, pues el arpón es un arma que hiere o mata. En cambio, el filamento en cuestión se pega, se adhiere y también el óvulo tiene moléculas adherentes. ¿Por qué no centrarse en esto? 0 ¿por qué no usar otras metáforas, como la de "tender un cable" o "construir un puente"?

Otro caso en el que se sigue utilizando la metáfora del óvulo pasivo, a pesar de que las investigaciones parezcan hablar de un modelo "igualitarista" lo hallamos en Wassarman (1988). Al dar cuenta de las investigaciones realizadas con esperma y óvulos de ratones para identificar las moléculas específicas de la zona externa del óvulo o zona pellúcida que intervienen en la interacción óvulo-esperma, parece optar por un lenguaje igualitario, pues dice que los gametos masculino y femenino se reconocen entre sí e interaccionan. Sin embargo, habla de la primera vez que Fol, un fisiólogo suizo, vio a través del microscopio cómo el espermatozoide penetraba el óvulo y lo fertilizaba, produciendo el embrión. Además de que el sujeto de la frase es el espermatozoide, siendo el objeto el óvulo, obsérvese una vez más ese carácter activo del espermatozoide. Pero lo más sobresaliente de todo es que el objetivo del artículo es dar cuenta del descubrimiento de la ZP3, una molécula de la zona pellúcida del óvulo que desempeña un importante papel en la fertilización y a la que da el nombre de "molécula receptora de esperma", volviendo a asignar al óvulo, de ese modo, un papel pasivo: "El proceso básico comienza cuando varios espermatozoides atacan suavemente y luego se unen tenazmente a las moléculas receptoras de la delgada capa externa del óvulo, la zona pellúcida. Cada espermatozoide, que posee en su superficie un montón de proteínas que se unen al óvulo se une a muchos receptores de esperma del óvulo. Dicho de modo más específico, una parte de cada una de las proteínas que se unen al óvulo encaja en un lugar complementario del receptor de esperma, del mismo modo que la llave encaja en la cerradura". La metáfora de la llave y la cerradura está clara: la llave entra, gira, en una cerradura que es una mera actriz pasiva, un hueco que deber ser Ilenado, algo sobre lo que se actúa sin que haga nada.

Por supuesto que ha habido otras metaforizaciones del descubrimiento de la existencia de moléculas adherentes en el óvulo y en el espermatozoide. Unos pocos años después de los descubrimientos de la John Hopkins, los investigadores reconceptualizaron el proceso dándole al óvulo un papel más activo: la zona pellúcida se convertía en una cazadora agresiva de espermatozoides, cubierta de moléculas adhesivas que pueden capturarlo de golpe y pegarlo a su superficie. La conceptualización ahora corresponde a otro estereotipo cultural, el de la vampiresa devoradora de hombres, la mujer, amenaza agresiva y peligrosa. Esas imágenes asignan al óvulo un papel más activo a costa de parecer perturbadoramente agresivo. Al fin y al cabo, entre nuestros estereotipos femeninos también tenemos los procedentes del mito griego de Pandora y del de Eva: la primera abre la caja que hace que los males se esparzan sobre la humanidad; y la curiosidad de la segunda acarrea la expulsión del Paraíso por incitar a Adán a comer la manzana del árbol del conocimiento del bien y del mal ${ }^{12}$.

ARBOR Vol. 187747 enero-febrero [2011] 99-108 ISSN: 0210-1963 
Pero, volviendo a las preguntas del comienzo, ¿podriamos disponer de otras metáforas que no respondieran al

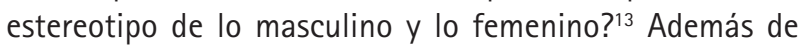
las alternativas ya mencionadas, la propia biología proporciona modelos aplicables a la fisiología reproductiva, por ejemplo, el modelo cibernético, con su adaptación flexible al cambio, la coordinación de las partes (óvulo y espermatozoide) con el todo (embrión), evolución en el tiempo y respuesta cambiante según el entorno. La metáfora cibernética es usual en genética, en endocrinología o en ecología y ha sido útil en medicina (por ejemplo en las enfermedades inmunológicas, aunque en este caso han ganado la batalla las metáforas bélicas, valga la doble metáfora). Se podria considerar entonces que el aparato reproductivo femenino se ajusta a los cambios mensuales (menstruación), responde a su entorno en el embarazo o la menopausia y es flexible, adaptándose a la reproducción y a la no reproducción. La interacción óvulo/esperma también se puede describir en términos del modelo cibernético, lo cual no significa que la metáfora cibernética sea siempre neutral ${ }^{14}$. Pero, son tan fuertes los estereotipos culturales al género, es decir, a los diferentes papeles que culturalmente se les asigna a mujeres y hombres, que esas metáforas son difíciles de disolver.

Este tipo de metáforas de género aparecen en otros muchos casos en los que ni siquiera el sexo está presente, poniéndose de manifiesto, una vez más, su papel en la ciencia y el carácter sociocultural de ésta. Tomemos el caso de las bacterias, tal y como viene explicado en uno de los libros de texto más influyentes en las universidades de todo el mundo: Molecular Biology of the Gene, de J. Watson et al..$^{15}$.

Como es sabido, las bacterias se componen de una sola célula microscópica y se parecen mucho entre sí. Esta célula carece de núcleo y en lugar de pares de cromosomas posee uno solo formado por ADN bicatenario. Además algunas bacterias, como la escherichia colli, poseen un plásmido, que es un elemento genético extracromosómico que se autorreplica y tiene forma de anillo. En el caso de esta bacteria, la transferencia genética se produce a través de un plásmido denominado $\mathrm{F}$ (por "fertilidad") con la ayuda de un puente, denominado pilus que es una pequeña protuberancia que sale de la superficie de la célula que contiene plásmido, denominada $F+$ y se une a otra célula que no tiene plásmido ( $F-$ ). El plásmido se replica y una de esas dos copias termina en la célula sin plásmido, que ahora es $\mathrm{F}+$, quedando la otra copia en la anterior célula, también F+. Los científicos denominaron a la célula donante macho y a la receptora hembra, es decir, a la que tiene plásmido, macho, y a la que carece de él, hembra. Muchos libros de biología molecular, como el citado, afirman que en la bacteria unicelular escherichia colli hay dos sexos distintos, desde que en los años 50 se descubriera, al cultivar dicha bacteria como organismo experimental, que a veces transfiere una parte de su material genético de una célula -esto es, del organismo completo- a otra (otro organismo completo).

En el citado texto de Watson et al. se dice: "Como en los organismos superiores, hay células macho y células hembra", a pesar de que inmediatamente después se señala: "estas dos [células] no se fusionan completamente, permitiendo que se mezclen sus dos conjuntos de cromosomas formando dos genomas diploides nuevos completos. En cambio, la transferencia es siempre unidireccional, pasando el material cromosómico masculino a las células femeninas; el movimiento inverso de los genes masculinos a las células hembra no se produce nunca.... En cultivos mezclados, rápidamente todas las células se convierten en células macho donantes"16. El lenguaje usado no deja lugar a dudas, pues se refieren a la relación como "uniones conyugales" entre células macho y hembra (ibidem, p. 4). Incluso en los experimentos realizados para elaborar el mapa del genoma de la bacteria, se denominaba "coitus interruptus" a la agitación de las bacterias para separar las que se habian conectado durante la transferencia genética.

La utilización de estas metáforas requiere algunas reflexiones. En primer lugar, hay que señalar que se está utilizando una sola definición de sexo ${ }^{17}$, a saber, genético, y su definición científica (intercambio de material genético entre organismos) con al menos dos significados culturales: por un lado, el acto sexual entre macho y hembra, es decir, la intimidad físico-sexual entre macho y hembra y que nada tiene que ver con ninguno de los tipos de sexo; por otro, la designación o asignación de género por la presencia de un significante masculino ("sexo", referido a un macho tiene más de un significado: miembro viril y también el género atribuido). En segundo lugar, se están imponiendo en seres unicelulares estereotipos claramente sexistas: la célula que tiene plásmido es la célula macho, es decir, la presen- 
cia de algo que cambia de tamaño, alargándose (¿como un pene?) hace que esa bacteria se considere "macho", mientras se define lo femenino como ausencia o carencia. Lo mismo por lo que se refiere a la célula que lanza el plásmido que es activa $y$, por tanto, macho, mientras que la que lo recibe de forma pasiva es la célula-hembra. En tercer lugar, el lenguaje no sólo es sexista sino que tiene, además, un claro sesgo heterosexista, pues presupone que las relaciones sexuales sólo se dan entre macho y hembra. Sin embargo, en este caso, ese intercambio supuestamente heterosexual cambia el sexo de una de las células, convirtiendo toda la población en células-macho: ¿cuáles serían las implicaciones culturales para la homosexualidad o la transexualidad?

Finalmente, habría que señalar una última cuestión. La presencia de plásmido es lo que asigna significado "masculino" a la bacteria; los plásmidos son instrumentos esenciales en la tecnología del ADN recombinante $y$, por lo que se sabe hasta la fecha, el ADN es la molécula controladora de la vida, lo que nos devuelve al discurso del poder de los genes ${ }^{18}$.

\section{Consideraciones finales}

La caracterización de la investigación científica que se impone con el nacimiento de la ciencia moderna ha sido objeto de investigación desde diversas perspectivas. Historiadoras e historiadores de la ciencia han mostrado los múltiples factores sociales y políticos que intervienen en los debates que se dan en la institucionalización de la ciencia moderna en la Inglaterra del siglo XVII. Por ejemplo, Robert K. Merton (1938) señaló el importante papel del puritanismo en este período, auténtico motor de la investigación al considerar un deber moral de los hombres [sic] ejercer el poder sobre la naturaleza, lo que les Ilevaría a la salvación ${ }^{19}$. Pero, no se puede entender el desarrollo de la ciencia moderna "sin prestar atención al papel que desempeñan las metáforas de género en la formación del conjunto particular de valores, propósitos y metas que la empresa científica encarna" ${ }^{20}$.

La conceptualización de la naturaleza estuvo siempre ligada a los estereotipos de la feminidad, pero, en el siglo XVII, cambia de la madre nutricia del Renacimiento a mujer díscola que necesita ser dominada ${ }^{21}$. Según la primera metáfora, la naturaleza es una madre que alimenta, que provee las necesidades de la humanidad en un universo planeado y ordenado; aunque a veces pueda ser incontrolable y produzca tormentas, inundaciones, caos en suma, ambas se identifican con lo femenino. Si la primera parte de la metáfora, la madre nutricia, se desvanece en la Revolución Científica, cuando el mundo se mecaniza y racionaliza ${ }^{22}$, también podemos decir que la segunda, la mujer incontrolable, da paso a la idea de dominación del poder de la naturaleza, de su fuerza caótica.

Según los críticos sociales e historiadores de la ciencia moderna, es Francis Bacon uno de los autores que determinan cuáles son los objetivos de la investigación científica, al establecer la relación fundamental entre conocimiento y poder: el objetivo de la ciencia es controlar y dominar la naturaleza. $Y$ en Bacon, las metáforas sexistas tienen un papel notorio. En efecto, para Bacon, el objetivo de la ciencia era devolverle al hombre la soberanía y el poder que tuvo en el anterior estadio de la creación. Cuando explica cómo, es cuando se ve el uso de metáforas e imágenes sexuales, de una complejidad no gratuita sino que se pueden interpretar "como parte de una descripción del impulso científico"23. Hay que establecer "un maridaje casto y legal entre Mente y Naturaleza", aunque ésta "requiere ser dominada, conformada y sometida por la mente del científico"24.

La conceptualización de la naturaleza que hace Bacon supone una novedad e impregna la ideología de la ciencia moderna a partir de entonces. Y los ecos de la metáfora baconiana de la ciencia que asimila la naturaleza a una mujer que debe ser controlada, dominada e incluso violada si es necesario para arrancarle sus secretos ${ }^{25}$ pueden aún oírse en nuestros días en la boca de científicos como Richard Feynman, quien, al recoger el Premio Nobel en 1965, se refería a las teorías científicas como jóvenes atractivas que han de ser "ganadas", pero que se convierten con el tiempo en viejas matronas ya no deseables, pero dignas de respeto; o la del filósofo Paul Feyerabend, que ve la naturaleza como una amante complaciente (cit. en Rose, 1994: 17-18).

Nuestros estereotipos y creencias de género tienen un gran poder y función en nuestra cultura. Las atribuciones de género (y los estereotipos y sesgos sexistas asociados) son consistentes con las ideas y concepciones del mundo 
de las personas que crean conocimiento científico. Estas mismas personas las incluyen en el conocimiento que generan, contribuyendo de este modo a incorporarlas como "hechos científicos" con la carga de autoridad que eso conlleva. Así, las metáforas que usan los biólogos para describir sus datos tienen importantes consecuencias no sólo cognitivas, sino sociales, que a veces quedan ocultas porque están tan arraigadas que parecen obvias. Porque uno de los factores que hace aceptable las metáforas en ciencia es su aparente falta de arbitrariedad.

Las metáforas proporcionan una forma de pensar sobre el campo de estudio, sobre los objetos o componentes que interactúan, que, una vez "visualizado" o "pensado" se convierte en nuevas formas de conocimiento que, a su vez, puede resultar en una nueva forma de control social que se puede ejercer sobre los componentes del campo ${ }^{26}$. Unas metáforas son mejores que otras, se aceptan con mayor facilidad y oponen una gran resistencia a ser removidas 0 eliminadas del lenguaje científico porque revelan de una forma muy clara un conocimiento social compartido. La efectividad de las metáforas depende de las convenciones sociales compartidas, de los parecidos de familia ya vigentes $y$, seguramente de manera primordial, de la autoridad que, por convención, se otorga a quienes las usan. Las metáforas que en algún momento fueron socialmente eficaces, pueden dejar de serlo gracias, en parte, a los cambios en la ideología de género.

La crítica de esas y otras metáforas puede mostrar cómo los científicos usan a menudo metáforas pobres debido a que compromisos no explícitos o supuestos sexistas, con jerarquías de género o de otro tipo, deforman su juicio de un modo que no pueden ver. Cierto tipo de metáforas, como algunas aquí señaladas, pueden cambiar el régimen de verdad relegando a ciertos grupos a un estatuto de inferioridad. Eliminarlo es muy dificil y exige análisis y prácticas muy sutiles, como pueda ser el desenmascaramiento de esas metáforas que ayudan a mantener la configuración genéricamente sesgada de la sociedad.

\section{NOTAS}

1 Este trabajo ha sido realizado, en parte, dentro del proyecto de investigación financiado dentro del Plan Nacional de I+D+I, HUM 200606327-FISO.

2 Lakoff y M. Jhonson (1980, 1999), Bustos, 2000.

3 En todas estas citas, el énfasis añadido es nuestro.

4 Algunos sociobiólogos utilizan la metáfora del gasto o desperdicio para justificar papeles sociales de hombres y mujeres. Así, por ejemplo, el "gasto" que tienen las mujeres para producir sus gametos, les permite explicar que se dediquen a cuidar la progenie, en el hogar, y la fidelidad a una sola pareja. Pero también aqui se podría invertir la interpretación y pensar que con cuantos más machos (varones) se aparee una hembra, más posibilidades tendrá de sacar adelante a su progenie, pues se asegurará el cuidado de varios machos y no el de uno sólo (como de hecho sucede en varias especies de primates). Véase, por ejemplo, Pérez Sedeño, 2008.

5 Tal y como aparecen mujeres y hombres en libros de "psicología popular" como Por qué los hombres no escuchan y las mujeres no entienden los mapas, Allan y Barbara Pease.

6 Que recuerde, sólo en la película de Woody Allen (1972), Todo lo que Vd. siempre quiso saber sobre el sexo (pero nunca se atrevió a preguntar), el guión se aparta de esos estereotipos, precisamente para caricaturizarlos cuando Tony Randall, Burt Reynolds y Woody Allen aparecen como espermatozoides que tienen dobles pensamientos acerca de la eyaculación.

Aceptado: 10 de diciembre de 2009 
En concreto, el actor-director está aterrado ante su inminente salida al mundo exterior y con graves preocupaciones metafísicas.

7 Keller (1995), p. 23.

8 Keller, 2000.

9 Las cualidades femeninas no serian aptas para el desempeño de la actividad científica. Véase Pérez Sedeño 2006, 2008.

10 También aquí el énfasis añadido es nuestro.

11 El acrosoma es un pequeño depósito situado en el extremo apical de la cabeza del espermatozoide y que contiene enzimas proteolíticas. Las otras partes del espermatozoide son el cuerpo basal y la cola o flagelo.

12 Sobre estos y otros mitos filosóficos (como las ideas de Platón que aparecen en el Timeo), o cientificos (como las biológicas de) que han conformado los estereotipos de lo masculino y lo femenino véase, por ejemplo, Tuana (1993) o Pérez Sedeño (2008).

13 Sobre metaforizaciones alternativas y recursos retóricos para desafiar las metáforas sexistas véase, por ejemplo, Herschberger (1948) o Tomlinson (1995).

14 Por ejemplo, la metáfora cibernética desempeñó un papel importante en los años cincuenta a la hora de imponer/desarrollar nuevas formas de control social.

15 Traducida a más de 30 idiomas y con múltiples ediciones, la primera traducción al español fue en 1978 y la última en 2008.

16 Op. cit., p. 191. Una vez más, el énfasis añadido es nuestro.

170 , si se quiere, un único tipo o aspecto $y$, como es sabido, hay diversos, como sucede con el género. Véase, por ejemplo, Fausto-Sterling (2000) o Pérez Sedeño (2006).

18 Véase, por ejemplo, Keller, 1995, 2000.
19 Merton no cayó, en cambio, en la exclusión de las mujeres.

20 Keller (1985), p. 51.

21 Carolyn Merchant (1980).

22 Sobre los orígenes de los estereotipos que asocian lo racional, etc., a lo masculino, véase, por ejemplo, Tuana, 1993, o Pérez Sedeño, 2008.

23 Keller (1985), p. 43.

24 F. Bacon, Novum Organum, citado en Keller, 1985.

25 Keller (1985), pp. 41-50.

26 Por ejemplo, la psicología conductista se convirtió (o pretendió convertirse) en una suerte de ingeniería social. Cuando la medicina comenzó a reconocer la importancia del entorno psicosocial del paciente (la familia y su psicodinámica) ciertas profesiones (trabajadores sociales) comenzaron a fijarse en ese entorno y el conocimiento resultante se convirtió en una nueva forma de controlar al paciente: los pacientes ya no eran cuerpos aislados, individuales, sino entidades psicosociales localizadas en un entorno, en un sistema ecológico: controlar la psicología del paciente era una nueva manera, otra vía, de controlar al paciente (enfermos de sida, cáncer o Alzheimer).

\section{REFERENCIAS}

Alberts, Bruce, et al. (1994): Molecular Biology of the Cell, Nueva York: Garland.

Bustos, Eduardo (2000): La metáfora. Ensayos transdisciplinares, Madrid: FCE.

Fausto-Sterling, Anne (2000): Sexing the Body: Gender Politics and the Construction of Sexuality, Nueva York: Basics Books.

Herschberger, Ruth (1948): Adam's Rib, Nueva York: Pellegrini \& Cudahy. Reimpreso por: Harper and Row, 1970.
Hesse, Mary (1966): Models and Analogies in Science, Notre Dame: Notre Dame University Press.

Keller, Evelyn Fox (1985): Reflexiones sobre género y ciencia, Valencia: Alfons el Magnànim, 1991.

- (1995): Refiguring Life: Metaphors of Twentieyh-Century Biology, Nueva York: Columbia Univ. Press.

- $\quad$ (2000): The Century of the Gene, Harvard Univ. Press, trad. esp. de Juan Pedro Campos, El siglo del gen, Barcelona: Ed. Península, 2002.

Lakoff, George y Mark Johnson (1980): Metaphors We Live By. Chicago: Chicago University Press; trad. cast. 1986. Metáforas de la vida cotidiana, Madrid: Cátedra.

Lakoff, George y Mark Johnson (1999): Philosophy in the Flesh. The Embodied Mind and Its Challenge to Western Thought, New York: Basic Books.

Martin, Emily (1987): The Woman in the Body. A Cultural Analysis of Reproduction, Boston: Beacon Press.

- $\quad$ (1991): "Egg and Sperm", Signs: Journal of Women in Culture and Society, 16, 3.

Merchant, Carolyn (1980): The Death of Nature: Women, Ecology, and the Scientific Revolution, San Francisco: Harper.

Merton, Robert K. (1938): Science, Technology and Society in Seventeenth Century England. OSIRIS: Studies on the History and Philosophy of Science and on the History of Learning and Culture, Bruges, Belgium: St. Catherine Press [New York: Harper \& Row, 1980; New York: Howard Fertig, Inc., 1980, 2002].

Mountcastle, Verenon (1980): Medical Physiology, 14th ed., Londres: Mosby.

Pérez Sanz, Pilar (1998): La quinta libertad. Guía de métodos anticonceptivos, Madrid: Ed. Pirámide.

Pérez Sedeño, Eulalia (2006): "Sexos, Géneros y Otras Especies: Diferencias Sin 
Desgualdades", en Catalina Lara (ed.), El segundo escalón. Desequilibrios de Género en Ciencia y Tecnología, SeviIla: Arcibel Eds.

- (2008): "Mitos, creencias, valores: cómo hacer más 'científica' la ciencia; cómo hacer la realidad más 'real'", Isegoría, 38 (enero-junio).

Rayner, Carl (1985): El Cuerpo Humano, 2 vols., Barcelona: Orbis.
Rose, Hilary (1994): Love, Power, and Knowledge:Towards a Feminist Transformation of the Sciences, Indiana: Indiana Univ. Press.

Tomlinson, Barbara (1995): "Phallic Fables and Spermatic Romance: Disciplinary Crossing and Textual Ridicule", Configurations, 3.2, pp. 105-134.

Tuana, Nancy (1993): The Less Noble Sex. Scientific, Religious and Philosophi- cal conceptions of Woman's Nature, Bloomington: Indiana Univ. Press.

Wassarman, Paul M. (1988): "Fertilization in mammals". Scientific American, 259 (6): 78-84.

Watson, James et al. (1987): Molecular Biology of the Gene, Benjamin/Cummings, Menlo Park, California (1. ${ }^{\mathrm{a}}$ edición, 1965, W.A. Benjamin, New York). 